\title{
Urban Farming With The Biopharmaceutical Crops To Develop Micro, Small And Medium Enterprises (Msme) Of Healthy Beverages Production
}

\author{
Tuti Setyaningrum, Sari Virgawati, Maftuh Kafiya \\ Universitas Pembangunan Nasional Veteran Yogyakarta \\ E-mail address tuti.setyaningrum@upnyk.ac.id; E-mail address \\ kafiyamaftuh@upnyk.ac.id
}

\begin{abstract}
Recently, it is quite difficult to find an area for cultivation in the city, therefore, the backyard area in every family house in the city is also used as a farming area known as the urban farming system. The Farmer Group in the city of Yogyakarta, namely the Wijaya Kusuma Farmer Group (WK), has developed this urban farming system in their home yards by growing vegetables and fruits. With the COVID pandemic, they plan to cultivate empon-empon, herbal plants which have benefits to increase the body immunity or known as biopharmaceutical crops. Meanwhile, the Lombok Ijo Farmer Group (LI), which is in the same area as the WK, is more oriented towards making a healthy beverage from empon-empon. However, in this pandemic situation, the price of raw material for herbal drink has increased significantly. In this case, a collaboration between those two farmer groups is needed by utilizing the empon-empon cultivation produced from the WK to meet the raw material needs for herbal drinks produced by the LI. To ensure that both farmer gro ups reach good quality products and able to meet the standards for developing SMSE, it needs to assist in cultivation, post-harvest processing, until product packaging, and marketing by training.
\end{abstract}

Keywords: Urban Farming, Empon-Empon, Biopharmaceutical Crops, Healthy Beverages, SMSE

\section{INTRODUCTION}

This is an open access article under the CC-BY-NC license.

State When the Corona-virus disease (COVID-19) pandemic hits the world, people with weak immunity will be easily infected. Various efforts have been made to combat COVID, for which no cure has been found. One of them is through intake that can increase endurance. One of the agricultural plants that have the potential as medicine and can increase body resistance is jamu (herbal medicine). Market demand for medicinal plants is increasing due to the number of people who are aware of the importance of maintaining health. This is a 
great opportunity to increase the production of empon-empon (medicinal plants) with the quality desired by the market.

However, with the decreasing of farming area, it is quite difficult to develop the cultivation of these herbal plants, therefore, the backyard area in every family house in the city is also used as a farming area known as the urban farming system. The Farmer Group in the city of Yogyakarta, namely the Wijaya Kusuma Farmer Group (WK), has developed this urban farming system in their home yards by growing vegetables and fruits. With this COVID pandemic, they plan to cultivate empon-empon. Meanwhile, the Lombok Ijo Farmer Group (LI), which is in the same area as the WK, is more oriented towards making herbal beverage products. However, with this COVID, the price of raw material for herbal drinks has increased significantly. In this case, a collaboration between those two farmer groups is needed by utilizing the empon-empon cultivation produced from the WK to meet the raw material needs for herbal drinks produced by the LI. Therefore, they can have a high selling value and improve their family economy as well.

Cultivation of herbal plants must be carried out by Good Agricultural Practices (GAP) so that the quality of empon-empon products can be absorbed by the market with good selling value. The processing of herbal drinks must also be done properly by Good Manufacturing Practice (GMP).

It needs to assist in cultivation, post-harvest processing, until product packaging, and marketing, to ensure that both farmer groups reach good quality products and able to sustain their productivity to meet the standards for developing SMSE

\section{LITERATURE REVIEW}

The productive crops are needed for consumption and it is also to improve the environment from oxygen provisioning, an antidote to air pollution, and to improve soil conditions. The use of the yard for horticultural crops (vegetables, fruits, and ornamental plants), spices medicines, herbs, etc. can benefit the owners of the yard particularly and the general public (Indrawati, 2017). The plots in each urban household are generally narrow land to crop the plant. However, there are many ways to optimize the narrow land through urban farming (Wachdijono, et. al., 2019).

Urban agriculture offers an alternative land use for integrating multiple functions in densely populated areas. While urban agriculture has historically been an important element of cities in many developing countries, recent concerns about economic and food security have resulted in a growing movement to produce food in cities of developed countries (Lovell, 2010). The activities of urban farming, in general, has a very important because it is needed in support of food security with the availability of adequate food. The main issue is producing high-quality agricultural products in densely populated areas and environmental pollution (Cahya, 2016).

The development of sustainable agriculture seeks to achieve sustainability of agricultural production, rural economic sustainability, and environmental sustainability in the long term) (Li, 2009). Irwan, et.al (2018), states the production of the yard has a function to help the economy of the family and from the yard can produce some products to sold and become 
business at home. Utilization of 'pekarangan' will develop a productive landscape to support food production for household and social interaction facilities with neighbors. The optimization of yards is not only for individuals from one family but in groups with people around at home.

Nurhayati and Swastika (2011), states that the existence of groups farmers is very important in the community, not only in the independence of food but also independence of health through the development of medical/ herbal plants. Herbal plants are not only to be medicine but used as functional foods that can maintain stamina for the body (Hariyani, 2020). Functional food is a food product that provides health and prevents disease. Herbal plants such as ginger, turmeric, aloe vera, kencur, and other herbal plants are functional food (Harijono and Sriherfyana, 2016).

Cultivation of herbal plants must be carried out with the guidance of Good Agricultural Practices (GAP), so the quality of herbal plans can be a good product. Also, the handling and processing of herbal plants must be properly with the guidance of Good Manufacturing Practices (GMP) (Iftitah and Haryono, 2008).

Small companies tend to be vulnerable during an economic crisis, in part because they have fewer resources with which to adapt to a changing context. The ITC COVID-19 Business Impact Survey gathered evidence on how the pandemic affected 4,467 companies in 132 countries (ITC, 2020).

\section{RESEARCH METHODOLOGY}

The objectives of urban farming socialization are Farmer Group of Wijaya Kusuma (RW 05) and Farmer Group Lombok Ijo (RW 04) Demangan village, District of Gondokusuman in July 2020. The target of this activity are members of both farmer group respectively 20 people/group. Activity methods are lectures, discussions, and training of cultivation and postharvest handling and processing of herbal plants.

\section{FINDING AND DISCUSSION}

Demangan village Gondokusuman district is located in the northeast of Yogyakarta city. Urban farming in Demangan village was applied by the Wijaya Kusuma farmer group and Lombok Ijo farmer group. Both have various kinds of herbs and vegetables that are planted. They optimized the small land in their area to create a garden in the middle of the urban area. The market demand for herbal plants was increased due to the COVID-19 pandemic. This is a great opportunity to increase the production and quality of the product that was required based on market needs. Most of the participants stated that the cultivation of herbal plants, especially red ginger that had been planted in their garden had bad quality, many leaves but small tubers. Therefore, they need training and assistance in the cultivation of herbal plants. 
Socialization activity held on the team from Faculty of Agriculture UPN "Veteran" Yogyakarta consist of counseling activities about benefits of crops herbal plants, how to cultivate herbal plants in the narrow yard and processing practices herbal plants have 4 steps. The first activity was a lecture with the topic of is the benefits of herbal plants for the body which used as a guard against immunity to defeat the coronavirus. The lecture was held 2 hours inside room meeting of Demangan village using strict health protocols; using masks, face shields, and social distancing during the event. The participants were very enthusiastic and very interested in cultivating herbal plants. The stadium general was given to the Wijaya Kusuma farmer group and Lombok Ijo farmer group. Discussion sessions were also to understanding participants about the topic
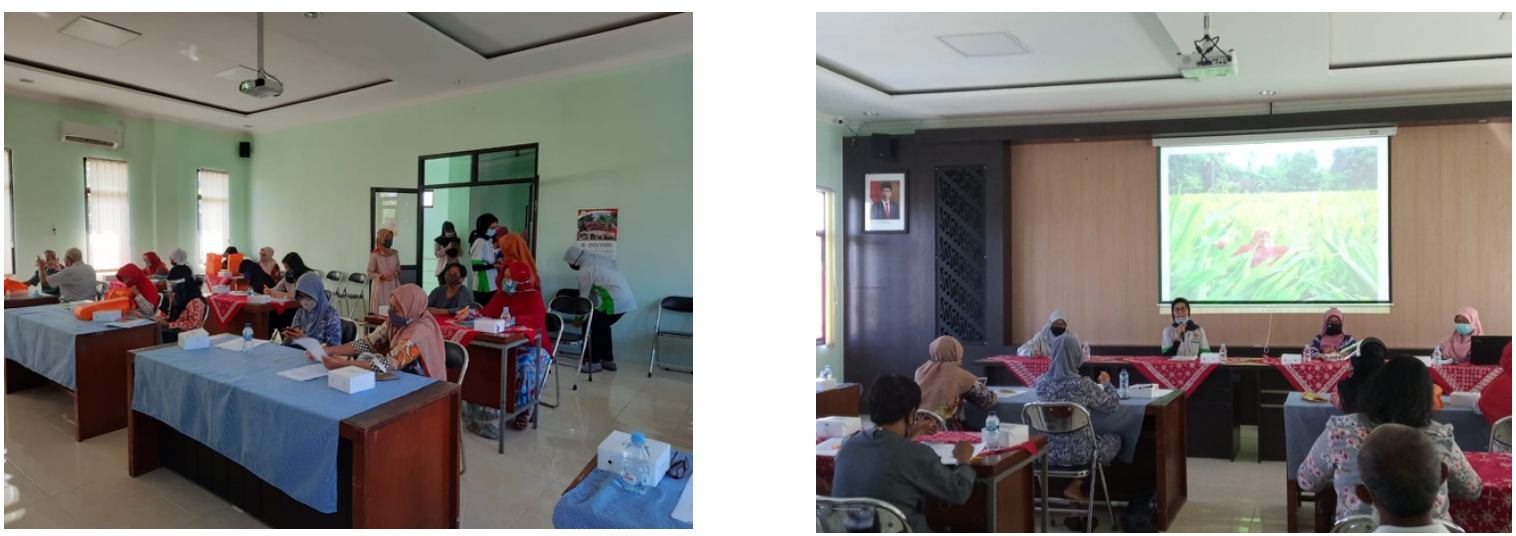

Figure 1. Lectures And Discussion About The Function Of Crops Herbal Plants

The second activity is workshop or training cultivation red ginger in the garden of the Wijaya Kusuma farmer group. This one-day workshop taught members of the Wijaya Kusuma farmer group to plant red ginger using polybags with the Trichoderma as a biological agent to reduce the risk of infection. Participants were also taught about Good Agriculture Practices (GAP) for ginger.

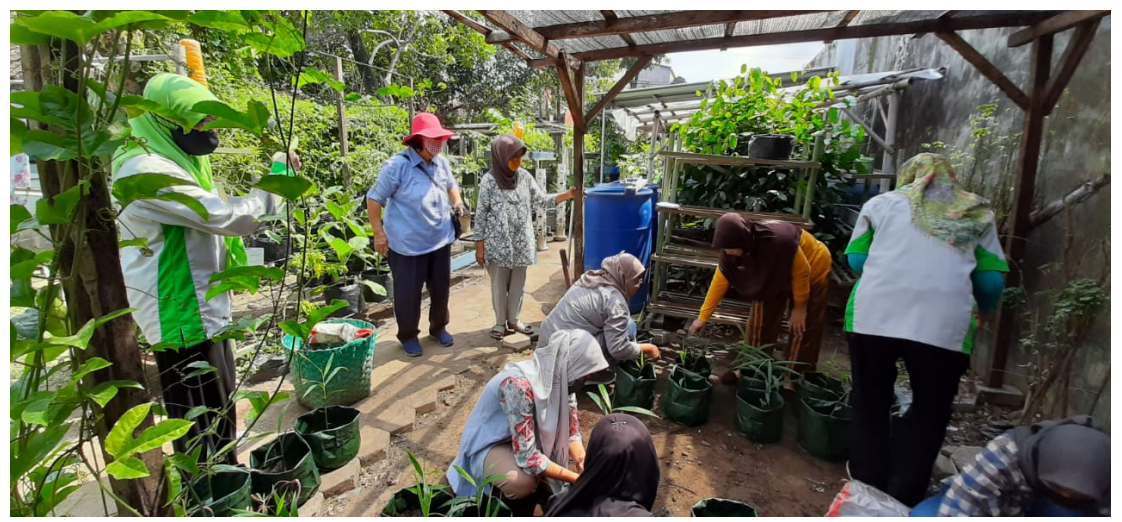

Figure 2. Training cultivation red ginger with Trichoderma as a bio-agent 


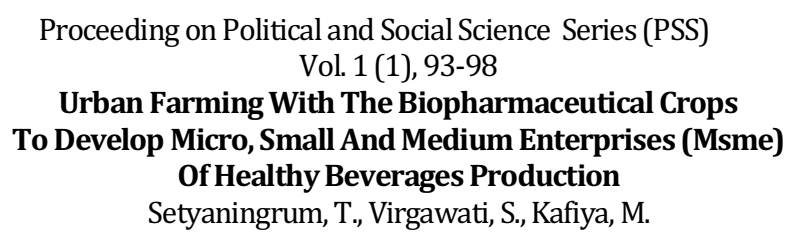

For maintenance pest and disease management ginger need to observe by regular. Sanitize tools, especially if used in handling infected plants, and keep animals away from the ginger plits. The third activity is care assistance which is carried out once a week. Assistance activities not only carry out maintenance but also discussion about plant media, watering, adding fertilizer, etc. this periodic mentoring activity is very good for controlling and evaluating the activities of the participants.

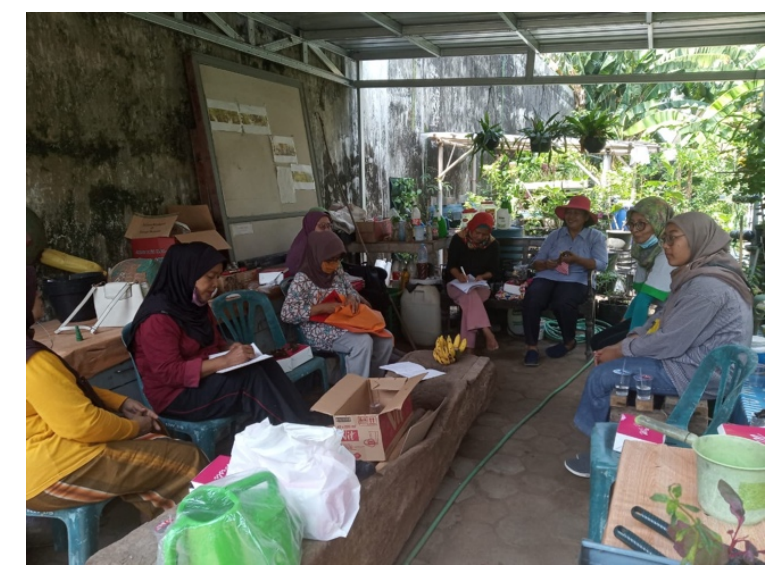

Figure 3. Discuss maintenance red ginger plant

The fourth activity was a workshop on post-harvest handling and processing of herbal plants conducted at the Lombok Ijo farmer group. Previously, the Lombok Ijo farmer group had made instant ginger by routine processing. But, after pandemic COVID-19, the productionintent ginger was stopped. Trisilawati, et.al (2020), states that jamu is an Indonesian herbal medicinal product, as part of the traditional natural health care of Indonesia's national cultural heritage. Jamu raw material consists of a single preparation or combination of several types of nutritious medicinal plants, collected from nature and cultivated by farmers. In this workshop, participants were taught how to make an instant ginger drink with red ginger as the raw material. Meanwhile, the additional ingredients that are given to strengthen the taste, there are lemongrass, fennel, cardamom, second, cloves, and sugar for easier the crystallization process.

\section{CONCLUSION AND FURTHER RESEARCH}

Socialization activities are carried out 4 stages, lectures, herbal plant cultivation workshops, herbal plant cultivation assistance, and instant herbal processing workshop. The four stages of these activities are aimed at adding added value to each farmer group in Demangan village. The hope is that the Wijaya Kusuma farmer group can collaborate with the Lombok Ijo farmer group by becoming a supplier of raw materials for an herbal instant drink made by the Lombok Ijo farmer group. So sustainable agriculture in Demangan village will be held.

\section{REFERENCES}


Cahya, D. L. (2016). 'Analysis of urban agriculture sustainability in Metropolitan Jakarta (case study: urban agriculture in Duri Kosambi)', Procedia Social and Behavioral Sciences, 227, p95-100.

Harijono dan Sriherfyna, F.H. (2016). 'Peningkatan Kapasitas dan Efisiensi Produksi Minuman Kesehatan Instan dan Kemasan CUP', Jurnal Teknologi Pangan, 7(3), p154160.

Hariyani, N. (2020). Bahan Ajar "Analisa Usaha Produksi Pengolahan Hasil Tanaman Obat Rimpang”. Malang: Kementrian Pertanian RI Badan Penyuluhan dan Pengembangan SDM Pertanian Balai Besar Pelatihan Pertanian Ketindan Malang.

Iftitah S.N., dan Haryono, G. (2018). 'Pengkajian Beberapa Tanaman Empon-Empon di Desa Balesari Kecamatan Windusari Kabupaten Magelang'. VIGOR: Jurnal Ilmu Pertanian dan Subtropika, 3(1), p13-16.

Indrawati, E. (2017). 'Urban Farming Model in South Jakarta'. The 4th International Seminar on Sustainable Urban Development, IOP Conf. Series: Earth and Environmental Science 106. [Online]. Accessed at: https://iopscience.iop.org/article/10.1088/17551315/106/1/012052

Irwan, S.N.F., Rogomulyo, R., Trisnowati, S. (2018). 'Utilization of "Pekarangan" through Productive Landscape Development in Mangunan Village, Bantul District Yogyakarta', Jurnal Ilmu Pertanian Indonesia (JIPI), 23(2), p148-157. 